\title{
MANAJEMEN HIPOKALEMIA PADA PASIEN DENGAN KRISIS HIPERGLIKEMIA
}

\author{
Dewi Rachmawati \\ Jurusan Keperawatan, Poltekkes Kemenkes Malang \\ Email: dewi_rachmawati@poltekkes-malang.ac.id
}

\begin{abstract}
Abstrak
Krisis hiperglikemia merupakan salah satu kegawatdaruratan metabolik yang dapat menyebabkan kematian atau kecacatan. Komplikasi yang sering terjadi pada pasien krisis hiperglikemia adalah hipokalemia. Komplikasi ini merupakan kondisi life-threatening electrolyte abnormalities yang berhubungan dengan cardiovascular emergency yang berkontribusi terhadap terjadinya aritmia yang mengancam nyawa bahkan sampai kematian. Tujuan literatur ini mengetahui manajemen hipokalemia pada pasien dengan krisis hiperglikemia. Sumber literatur dari artikel elektronik seperti ScienceDirect, Pubmed, Cochrane Library dengan kriteria publikasi periode 2010-2021 pencarian menggunakan kata kunci management, hypokalemia, hyperglycemic, crises. Hasil penelusuran didapatkan 21 artikel tentang prevalensi, monitoring dan manajemen hypokalemia pada hiperglikemia, hanya 7 artikel yang memenuhi kriteria inklusi. Literature review menunjukkan bahwa penanganan krisis hiperglikemia dengan pemberian insulin akan memperberat kondisi hipokalemia. Karena hipokalemia merupakan abnormalitas elektrolit yang mengancam nyawa maka diperlukan manajemen yang tepat pada pasien krisis hiperglikemia yang mengalami hipokalemia. Penatalaksanaan hipokalemia yang tepat dengan monitoring terus menerus oleh perawat akan mencegah terjadinya aritmia, cardiac arrest bahkan kematian pada penderita.
\end{abstract}

Kata kunci: Manajemen, hypokalemia, hiperglikemia

\begin{abstract}
Management Of Hypokalemia In Patients With Hyperglycemic Crisis. The hyperglycemia crisis is one of the metabolic emergencies that can cause death or disability. This hypokalemia is a frequent complication in patients with hyperglycemia crisis and is a life-threatening electrolyte abnormality associated with cardiovascular emergencies that can contribute to life-threatening arrhythmias even to death. The purpose of this literature is to find out how to manage hypokalemia in patients with a hyperglycemia crisis. Literature sources from electronic articles such as ScienceDirect, Pubmed, Cochrane Library with publication criteria for the period 2010-2021 search using the keywords "management, hypokalemia, hyperglycemia, crises". Search results obtained 21 articles about the prevalence, monitoring, and management of hypokalemia in hyperglycemia, only 7 articles that met the inclusion criteria. A literature review shows that handling the hyperglycemia crisis by administering insulin will aggravate the condition of hypokalemia. Because hypokalemia is a life-threatening electrolyte abnormality, appropriate management is needed in hyperglycemic crisis patients who have hypokalemia. Proper management of hypokalaemia with continuous monitoring by nurses will prevent arrhythmias, cardiac arrests, and even death in patients.
\end{abstract}

Keyword: management, hypokalemia, hyperglycemia 


\section{Pendahuluan}

Krisis hiperglikemia adalah keadaan metabolik emergency yang dihubungkan dengan diabetes tidak terkontrol yang secara signifikan menyebabkan terjadinya kecacatan atau kematian. Krisis hiperglikemia ini dikarakteristikkan dengan defisiensi insulin relatif atau obsolut yang mencegah metabolisme karbohidrat didalam tubuh sehingga terjadi hiperglikemia berat. Krisis hiperglikemia ini dibedakan menjadi dua tipe yaitu Diabetic ketoacidosis (DKA) dan Hyperosmolar Hyperglycemic State (HHS) (McNaughton et al, 2011; NessOtunnu \& Hack, 2013).

Diabetic ketoacidosis adalah keadaan dimana kadar glukosa darah meningkat $\geq 250$ $\mathrm{mg} / \mathrm{dl}$ dengan disertai asidosis metabolik dan ketonemia. DKA ini biasanya berkembang dalam hitungan hari atau minggu dengan tanda dan gejala khas yang tampak dalam 24 jam terjadinya defisiensi insulin. Biasanya pasien datang di instalasi gawat darurat dengan keluhan poliuria, polidipsia, nafas bau buah-buahan, pernafasan kussmaul, hipotensi, aritmia, hiperventilasi, letargi, konfusi dan tidak jarang pasien sudah jatuh dalam kondisi koma. Sedangkan pada HHS walaupun kelihatannya tampak sama tetapi terdapat beberapa perbedaan dimana HHS merupakan kondisi mengancam nyawa yang dihubungkan dengan hiperglikemia berat (kadar glukosa $\geq 600 \mathrm{mg} / \mathrm{dL}$ ) yang disertai peningkatan kadar osmolaritas dalam darah. Biasanya pasien dengan HHS datang ke instalasi gawat darurat sudah dalam keadaan koma yang disertai tanda dan gejala khas yang lain seperti mulut kering dan rasa haus yang extreme karena dehidrasi berat, kulit kering, letargi, poliuria, polidipsia, penurunan BB yang signifikan serta bisa juga disertai gejala mimic cardiovascular accident, kejang, hemiparesis dan aphasia (Cherlene et al, 2013; Ness-Otunnu \& Hack, 2013; Huang et al, 2013).

Di dunia angka kejadian diabetes meningkat dengan tajam. Pada tahun 2010 terdapat 285 juta orang dewasa menderita diabetes, dengan angka kejadian 16,2 per 1000 orang dewasa yang mengalami krisis hiperglikemia (Pollock \& Funk, 2013; NessOtunnu \& Hack, 2013). Sedangkan angka kematian untuk krisis hiperglikemia adalah tinggi yaitu untuk DKA angka kematian antara 1\%-9\%, HHS 5\%-45\%, 5\%-25\% untuk campuran antara HHS \& DKA dengan angka kematiannya yang semakin meningkat tajam pada usia >65 tahun yaitu $71 \%$ (Huang et al, 2013). Penyebab utama terjadinya kematian tersebut adalah hipokalemia berat, 
ARDS (Adult respiratory distress syndrome), pneumonia, koma dan infeksi (Dhatariya, 2014; Huang et al, 2013).

Hipokalemia pada pasien krisis hiperglikemia adalah penurunan kadar kalium dalam tubuh $<3,5 \mathrm{mEq} / \mathrm{L}$ yang terjadi baik pada pasien dengan DKA maupun HHS. Hipokalemia ini adalah komplikasi yang sering terjadi pada manajemen pasien krisis hiperglikemia dan merupakan lifethreatening electrolyte abnormalitas yang berhubungan dengan cardiovascular emergency yang dapat berkontribusi terhadap terjadinya aritmia yang mengancam nyawa bahkan sampai kematian akibat cardiac arrest (McNaughton et al, 2011; Liamis et al, 2014; Cherlene et al, 2013; Gosmanov et al, 2018; Kinoshita et al, 2018).

Hipokalemia pada penderita krisis hiperglikemia terjadi karena peningkatan kadar glukosa darah melebihi kadar glukosa threshold ginjal yang menyebabkan glukosa disekresikan ke dalam urine akibatnya terjadi diuresis osmotik besar-besaran dalam tubuh sehingga terjadi kehilangan elektrolit dan dehidrasi berat. Pada kondisi HHS juga terjadi penurunan intake cairan akibat kegagalan kompensasi dari pusat haus atau ketidakmampuan pasien untuk minum dan terjadi mual muntah menyebabkan dehidrasi yang terjadi semakin berat, terjadi prerenal azotemia dan peningkatan level osmolaritas semakin berat. Keadaan tersebut akan mengakibatkan pasien semakin jatuh dalam kondisi dehidrasi, syok dan kehilangan kalium yang berlebihan atau hipokalemia (Glossop et al, 2012; Hurtado et al, 2021; Nanette \& Catherine, 2010).

Keadaan hipokalemia semakin berat dengan adanya insulin endogen dan insulin dari luar untuk menurunkan kadar glukosa darah. Menurut Choudhry et al (2014) dan Liamis et al (2014) menyatakan bahwa insulin yang berasal dari dalam tubuh akan mengaktifkan pompa $\mathrm{Na}^{+}, \mathrm{K}^{+}$ATPase yang akan meningkatkan perpindahan kalium ke dalam sel sehingga memicu hipokalemia ditambah lagi apabila pasien mendapatkan terapi insulin untuk menurunkan kadar glukosa darah akan semakin memicu hipokalemia bertambah berat. Keadaan hipokalemia berat ini akan mempengaruhi sistem kardiovaskuler dan meningkatkan resiko kematian pada pasien krisis hiperglikemia.

Berdasarkan penelitian yang dipublikasikan pada tahun 1960-1980 dilaporkan bahwa kejadian hipokalemia pada pasien krisis hiperglikemia adalah 0-4\% (Vishnu et al, 2014). Di dukung penelitian Arora et al (2011) yang menyatakan $3(5,6 \%)$ pasien dari 54 pasien DKA $(1,2 \%-15,4 \%)$ 
mengalami hipokalemia. Sedangkan kematian karena hipokalemia pada pasien krisis hiperglikemia belum diketahui secara pasti. Beberapa prospective studi dalam Carlotti et al (2013) menyatakan hipokalemia adalah faktor predisposisi aritmia ventrikel khususnya ventrikel fibrilasi dan ventrikel takikardi dengan resiko kematian lebih tinggi pada orang tua yang mempunyai riwayat iskemia miokard. Dalam penelitian Kjeldsen (2010) juga mengatakan bahwa pasien dengan hipokalemia mempunyai resiko tinggi terjadi kematian karena aritmia yang fatal dan sudden cardiac death. Kematian ini terjadi karena adanya pemindahan kalium yang sangat cepat selama resusitasi pada pasien krisis hiperglikemia sehingga akan menstimulasi life-threatening arrhythmia yang dapat menyebabkan kematian setelah treatment dilakukan (McNaughton et al, 2011).

Selain itu hipokalemia juga dapat menyebabkan disfungsi neuromuskuler, flaccid paralysis, hipotensi, palpitasi, letargi dan kelemahan otot pernafasan yang mengancam nyawa (Liamis et al, 2014; Cherlene et al, 2013; Gosmanov et al, 2018). Untuk itu pasien krisis hiperglikemia harus dilakukan manajemen yang tepat dan dilakukan pemeriksaan kalium terlebih dahulu sebelum pemberian insulin dilaksanakan. Apabila pasien sudah terjadi hipokalemia harus segera dilakukan penggantian kalium dan pemeriksaan kalium setiap 2 jam sampai kondisi pasien stabil serta monitoring jantung terus-menerus (McNaughton et al, 2011). Untuk mencegah akibat dari hipokalemia tersebut sebagai perawat di unit gawat darurat yang pertama kali berhadapan dengan pasien harus mampu mengenali dan mengetahui dengan pasti kondisi pasien dengan krisis hiperglikemia serta mampu melakukan implementasi yang tepat dalam manajemen pasien krisis hiperglikemia yang mengalami hipokalemia. Oleh karena itu berdasarkan ulasan diatas maka tujuan penulisan dalam studi literatur ini adalah membahas secara lebih detail terkait manajemen hipokalemia pada pasien dengan krisis hiperglikemia

\section{Metode}

Penelitian ini berjenis literature review yang menganalisis manajemen hipokalemia pada pasien dengan krisis hiperglikemia. Variabel independen adalah manajemen hipokalemia. Untuk variabel dependen adalah pasien krisis hiperglikemia. Populasi adalah semua jurnal penelitian tentang manajemen hipokalemia pada pasien krisis hiperglikemia. Sampel adalah jurnal hasil penelitian tentang 
manajemen hipokalemia pada pasien krisis hiperglikemia yang memenuhi kriteria inklusi. Kriteria inklusi jurnal yang digunakan dalam literature review ini adalah 1). Merupakan jurnal clinical reviews, 2). Jurnal yang membahas tentang krisis hiperglikemia di instalasi gawat darurat, 3). Jurnal yang dipublikasikan dalam rentang tahun 2010-2021.

Sumber literatur review dari artikel elektronik seperti ScienceDirect, PubMed and Cochrane Library dengan kriteria artikel yang dipublikasi periode 2010-2021 dengan menggunakan kata kunci"management, hypokalemia, hyperglycemic, crises. Hasil penelusuran didapatkan 21 artikel tentang manajemen pada pasien dewasa dengan krisis hiperglikemia, hanya 7 artikel yang memenuhi kriteria inklusi.

Metode perumusan dalam analisis literature review ini menggunakan $\mathrm{PICO}$ framework, yaitu $\mathrm{P}$ adalah pasien dengan krisis hiperglikemia, I adalah manajemen hipokalemia, $\mathrm{C}$ adalah penatalaksanaan hipokalemia pada krisis hiperglikemia, O adalah pencegahan/perbaikan hipokalemia pada pasien krisis hiperglikemia.

\section{Hasil}

Krisis hiperglikemia dapat menyebabkan penurunan total kalium dalam tubuh. Penurunan total kalium ini berbeda antara penderita DKA dan HHS. Pada penderita DKA penurunan total kalium dalam tubuh biasanya pada range $2-5 \mathrm{mEq} / \mathrm{L}$, sedangkan pada HHS adalah pada range 4-6 mEq/L (Goguen \& Gilbert, 2013). Hipokalemia pada pasien krisis hiperglikemia dapat disebabkan adanya perpindahan kation transeluler, diuretik osmotik besar-besaran dan gangguan gastrointestinal yang akan menurunkan kadar total kalium dalam tubuh. Berdasarkan Goguen \& Gilbert (2013) menyatakan bahwa penggantian kalium harus segera dilakukan jika pasien mengalami hipokalemia atau normokalemia. Untuk itu diperlukan penanganan dan manajemen yang tepat dalam pengantian kalium pada penderita krisis hiperglikemia. Akan tetapi terdapat perbedaan pendapat oleh beberapa ahli dalam pemberiannya. Berikut adalah rekomendasi yang dianjurkan: 
Tabel 1. Rekomendasi Pemberian Kalium pada Keadaan Hypokalemia

\begin{tabular}{|c|c|c|c|c|c|}
\hline \multirow[t]{2}{*}{ No. } & \multirow{2}{*}{$\begin{array}{l}\text { Level of } \\
\text { Evidence }\end{array}$} & \multirow{2}{*}{$\begin{array}{c}\text { Rekomendasi } \\
\text { Pemberian Awal } \\
\text { Kalium }\end{array}$} & \multicolumn{3}{|c|}{ Tindakan } \\
\hline & & & $\mathrm{K}^{+} \geq 5,3$ & $\begin{array}{c}K^{+} \mathbf{3 , 3}- \\
5,2\end{array}$ & $\mathrm{~K}^{+}<\mathbf{3 , 3}$ \\
\hline 1. & $\begin{array}{l}\text { Goguen \& } \\
\text { Gilbert } \\
(2013)\end{array}$ & 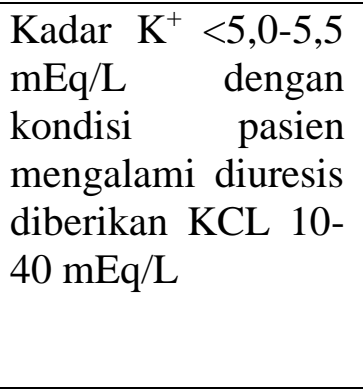 & - & $\begin{array}{l}\text { KCL 10- } \\
40 \\
\mathrm{mEq} / \mathrm{L}\end{array}$ & $\begin{array}{l}\text { Pemberian insulin } \\
\text { ditunda lebih dahulu dan } \\
\text { dilakukan pemberian } \\
\text { KCL } 40 \mathrm{mEq} / \mathrm{L} \text { (dengan } \\
\text { maksimal pemberian } 40 \\
\mathrm{mEq} / \mathrm{L} \text { ) sampai kadar } \\
\text { kalium mencapai } \geq 3,3 \\
\mathrm{mEq} / \mathrm{L}\end{array}$ \\
\hline 2. & $\begin{array}{l}\text { Pollock \& } \\
\text { Funk } \\
(2013), \\
\text { Ness- } \\
\text { Otunnu \& } \\
\text { Hack } \\
(2013)\end{array}$ & $\begin{array}{l}\text { Kadar } \mathrm{K}^{+}<5,0-5,2 \\
\text { mEq/L } \quad \text { untuk } \\
\text { mencegah } \\
\text { hypokalemia } \\
\text { dengan pemberian } \\
\text { KCL } \quad 20-30 \mathrm{mEq} \\
\text { setiap liter cairan. }\end{array}$ & $\begin{array}{l}\text { Cek serum } \\
\mathrm{K}^{+} \text {tiap } 2 \\
\text { jam }\end{array}$ & $\begin{array}{l}\text { KCL 20- } \\
30 \\
\mathrm{mEq} / \mathrm{L}\end{array}$ & $\begin{array}{l}\text { Pemberian insulin } \\
\text { ditunda lebih dahulu dan } \\
\text { dilakukan koreksi kalium } \\
20-30 \mathrm{mEq} / \mathrm{jam} \text { setiap } \\
\text { liter cairan sampai kadar } \\
\text { kalium mencapai >3,3 } \\
\text { mEq/L }\end{array}$ \\
\hline 3. & $\begin{array}{l}\text { Fayfman, } \\
\text { Pasquel, } \\
\text { Umpierrez } \\
\text { (2017) }\end{array}$ & $\begin{array}{l}\text { Kadar } \mathrm{K}^{+} \quad<5,2 \\
\mathrm{mEq} / \mathrm{L} \quad \text { dengan } \\
\text { pemberian kalium } \\
\text { 20-30 mEq/L untuk } \\
\text { mempertahankan } \\
\text { kadar kalium 4-5 } \\
\text { mEq/L }\end{array}$ & $\begin{array}{l}\text { Cek serum } \\
\mathrm{K}^{+} \text {tiap } 2 \\
\text { jam }\end{array}$ & $\begin{array}{l}\text { KCL 20- } \\
30 \\
\mathrm{mEq} / \mathrm{L}\end{array}$ & $\begin{array}{l}\text { Pemberian insulin } \\
\text { ditunda lebih dahulu dan } \\
\text { dilakukan koreksi kalium } \\
20-30 \mathrm{mEq} / \mathrm{jam} \text { setiap } \\
\text { liter cairan sampai kadar } \\
\text { kalium mencapai } \geq 3,3 \\
\text { mEq/L }\end{array}$ \\
\hline 4. & $\begin{array}{l}\text { McNaughto } \\
\mathrm{n} \text { et al } \\
(2011)\end{array}$ & - & $\begin{array}{l}\text { Cek setiap } \\
1 \text { jam }\end{array}$ & $\begin{array}{c}\mathrm{KCL} 20 \\
\mathrm{mEq} / \mathrm{L}\end{array}$ & $\begin{array}{l}\text { Tunda pemberian insulin } \\
\text { dan beri KCL } 20-60 \\
\mathrm{mEq} / \mathrm{L} / \mathrm{jam} \text { dan monitor } \\
\text { jantung }\end{array}$ \\
\hline 5. & $\begin{array}{l}\text { Westerberg } \\
(2013)\end{array}$ & $\begin{array}{l}\text { Kadar } \mathrm{K}^{+} \text {normal } \\
\text { diberikan KCL 10- } \\
15 \mathrm{mEq} / \mathrm{L}\end{array}$ & $\begin{array}{l}\text { Cek serum } \\
\mathrm{K}^{+} \text {setiap } 2 \\
\text { jam }\end{array}$ & $\begin{array}{c}\text { KCL 20- } \\
30 \\
\mathrm{mEq} / \mathrm{L}\end{array}$ & $\begin{array}{l}\text { Tunda pemberian insulin } \\
\text { dan berikan KCL } 20-30 \\
\text { mEq per jam }\end{array}$ \\
\hline
\end{tabular}


Biasanya dalam manajemen hipokalemia tidak bisa dipisahkan dengan manajemen krisis hiperglikemia secara keseluruhan sehingga saat manajemen krisis hiperglikemia tujuan koreksi kalium adalah untuk mencapai kalium antara 4,0-5,0 mEq/L atau 4,0-5,0 mmol/L. Dan yang perlu diperhatikan juga adalah apabila di awal penderita sudah mengalami hipokalemia maka sebelum memberikan insulin dilakukan koreksi hipokalemia terlebih dahulu karena pemberian insulin akan memperburuk pengurangan $\mathrm{K}^{+}$(Pollock \& Funk, 2013; Ness-Otunnu \& Hack, 2013; Fowler, 2009; Westerberg, 2013).

Bukti efektivitas dalam manajemen hipokalemia yang direkomendasikan didasarkan pada RCT dalam Connally (2002) pemberian kalium $20-30 \mathrm{mEq}$ per liter dapat secara adekuat mempertahankan level $\mathrm{K}^{+}$ pada rentang 4-5 $\mathrm{mEq} / \mathrm{L}$ dan saat level $\mathrm{K}^{+}$ $<3,3 \mathrm{mEq} / \mathrm{L}$ dapat mencegah terjadinya aritmia dan cardiac arrest. Diperkuat oleh penelitian Vishnu et al (2014) yang menyatakan bahwa pemberian kalium sesuai protokol yang direkomendasikan dalam 6 jam dapat meningkatkan level $\mathrm{K}^{+}$dan mengurangi paralisis otot serta dalam 24 jam level $\mathrm{K}^{+}$meningkat dalam batas normal dan paralisis hipokalemia menghilang. Selain itu guidelines untuk dilakukan pemeriksaan $\mathrm{K}^{+}$ sebelum pemberian terapi insulin dapat mencegah dan menurunkan terjadinya hipokalemia di unit gawat darurat (Arora et al, 2012)

\section{Pembahasan}

Perawat di instalasi gawat darurat sebagai ujung tombak perawatan di rumah sakit mempunyai peran vital dalam manajemen pasien dengan krisis hiperglikemia. Perawat di IGD harus mampu melakukan initial assessment untuk mengetahui tanda dan gejala krisis hiperglikemia, melakukan implementasi atau manajemen krisis hiperglikemia yang meliputi rehidrasi atau resusitasi cairan, memperbaiki dan mempertahankan kadar glukosa darah, koreksi kekurangan elektrolit dan kondisi asidosis, memberikan glukosa (dextrose) jika diperlukan dan mencegah komplikasi lebih lanjut (Pollock \& Funk, 2013). Kehilangan elektrolit sampai terjadi penurunan kadar elektrolit terutama kalium selalu terjadi pada manajemen krisis hiperglikemia. Karena pemberian insulin akan memperberat hipokalemia. Oleh karena itu diperlukan peran perawat dalam manajemen hipokalemia pada penderita krisis hiperglikemia (Pollock \& Funk, 2013; Cherlene et al, 2013). Berikut adalah 
protokol atau strategi penerapan manajemen hipokalemia pada penderita krisis hiperglikemia (Pollock \& Funk, 2013; NessOtunnu \& Hack, 2013; Grossmanov et al, 2018, Hurtado et al, 2021; Westerberg, 2013) 


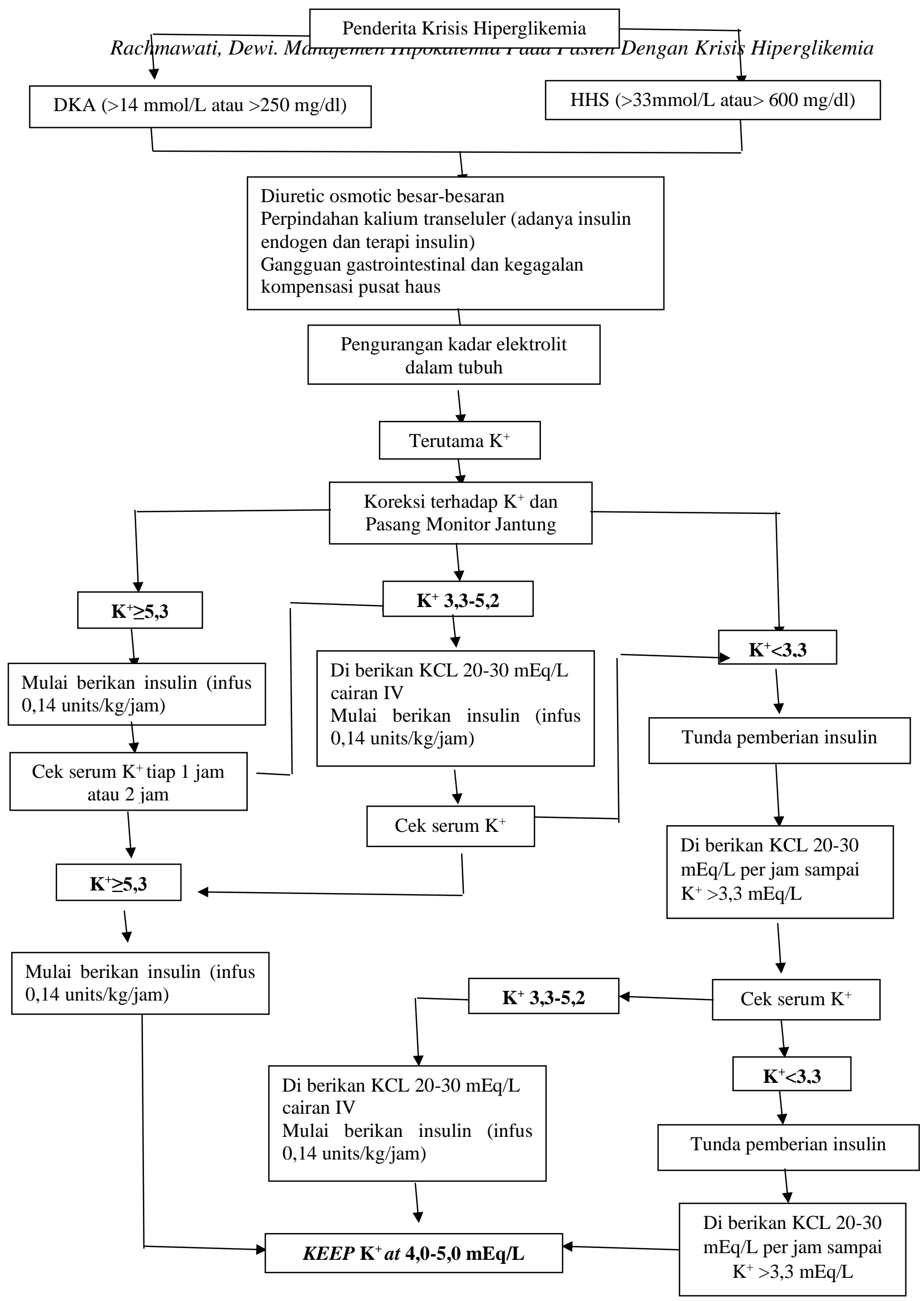

Bagan 1. strategi penerapan manajemen hipokalemia pada penderita krisis hiperglikemia 


\section{Keterangan:}

Dalam manajemen hipokalemia pada penderita krisis hiperglikemia sesuai protokol diatas yang harus diperhatikan oleh perawat adalah (Quality \& Patient Safety Committee, 2014; Cherlene et al, 2013):

1. Kadar kalium dalam darah

2. Monitoring jantung terus menerus untuk mengetahui adanya aritmia akibat hipokalemia

3. Cek kalium dalam darah setiap 6-8 jam setelah koreksi

4. Tanda dan gejala hipokalemia

5. Pemberian insulin untuk menurunkan kadar glukosa darah

6. Tempat atau insersi vena untuk pemasangan infus (KCL merupakan cairan yang sangat pekat dan mudah membuat iritasi atau plebitis oleh karena itu tempat pemasangan atau insersi vena harus di vena besar yaitu di lengan kanan atau kiri dan pasang dengan IV kateter jarum no.18G/20G. Jika penderita mendapatkan terapi KCL 40 $\mathrm{mEq} / \mathrm{L}$ maka harus diberikan melalui kateter vena sentral atau PICC line)

7. Pemberian KCL tidak boleh terlalu cepat atau diberikan IV bolus karena dapat menyebabkan kematian

8. Standard IV Potassium Solutions (20 $\mathrm{mEq}$ potassium chloride in $1000 \mathrm{~mL}$ sodium chloride $0.9 \%, 30 \mathrm{mEq}$ potassium chloride in $1000 \mathrm{~mL}$ sodium chloride $0.9 \%$ )

9. Tujuan koreksi kalium adalah untuk mencapai kalium antara 4,0-5,0 mEq/L

\section{Kesimpulan}

Krisis hiperglikemia merupakan metabolik emergency yang memerlukan penanganan segera. Dalam penanganan krisis hiperglikemia pemberian insulin akan memperberat kondisi hipokalemia. Karena hipokalemia merupakan abnormalitas elektrolit yang mengancam nyawa maka diperlukan manajemen yang tepat pada pasien krisis hiperglikemia yang mengalami hipokalemia. Penatalaksanaan hipokalemia yang tepat dengan monitoring terus menerus oleh perawat akan mencegah terjadinya aritmia, cardiac arrest bahkan kematian pada penderita.

\section{Saran}

Disarankan kepada perawat untuk mendeteksi dini segera krisis hiperglikemia pada pasien diabetes serta segera memberikan penatalaksanaan yang tepat untuk mencegah terjadinya hipokalemia. 


\section{Referensi}

Arora, Cheng, Wyler, \& Menchine. (2012). Prevalence of Hypokalemia in ED Patients with Diabetic Ketoacidosis. American Journal of Emergency Medicine, 30, 481-484. doi: doi:10.1016/j.ajem.2011.01.002

Carlotti, George-Hyslop, Bohn, \& Halperin. (2013). Hypokalemia during Treatment of Diabetic Ketoacidosis: Clinical Evidence for an Aldosterone-Like Action of Insulin. The Journal of Pediatric, 163(1), 207-212. doi: doi.org/10.1016/j.jpeds.2013.01.007

Cherlene, Pedrick, \& Harland. (2013). Hyperglycemic Crises: Managing Acute Complications of Diabetes. Texas: National Center of Continuing Education.

Diakses https://nursece.com/pdfs/620_Hypergl ycemicCrisis.pdf

Choudhry, Rajeshwari, Gururaja, Prabhu, \& Ravishankar. (2014). Retrospective Correlation of Fasting Glucose and Glycated Hemoglobin with Serum Electrolytes, Urea and Creatinine in Diabetic Patients. Asian Pacific Journal of Tropical Disease, 4, 5385$5388 . \quad$ doi: $10.1016 / \mathrm{S} 2222$ 1808(14)60475-8

Dhatariya. (2014). Diabetic Ketoacidosis and Hyperosmolar Crisis in Adults. Medicine, 42(12), 723-726. DOI: https://doi.org/10.1016/j.mpmed. 2014.09.012

Fayfman, Pasquel, Umpierrez. (2017). Management of Hyperglycemia Crises: Diabetic Ketoacidosis and Hyperglycemic Hyperosmolar State. The Medical Clinics of North America, 101 (3): 587-606

Fadini, Kreutzenberg, Rigato, Brocco, Marchesan, Tiengo, \& Avogaro. (2011). Characteristics and Outcomes of the Hyperglycemic Hyperosmolar
Nonketotic Syndrome in a Cohort of 51 Consecutive Cases at a Single Center. Diabetes Research and Clinical Practice, $\quad 94$, 172-179. doi:10.1016/j.diabres.2011.06.018

Glossop, Stanworth, \& Whiteside. (2012). Controversies and Pitfalls in the Management of Hyperglycaemic Crises in Critically ill Diabetic Patients. Trends in Anaesthesia and Critical Care, 2, 10-14. doi:10.1016/j.tacc.2011.10.002

Goguen, \& Gilbert. (2013). Hyperglycemic Emergencies in Adults. Canadian Journal of Diabetes, 37, 572-576. doi: http://dx.doi.org/10.1016/j.jcjd.2013.0 1.023

Gouveia, C. F, \& Chowdhury, T.(2013). Managing Hyperglycaemic Emergencies: an illustrative Case and Review of Recent British Guidelines. Clinical Medicine (London, England), 13(2), $160-2$. doi:10.7861/clinmedicine.13-2-160

Gosmanov, Aidar, Gosmanova, Elvira, Kitabchi, Abbas. (2018). Hyperglycemic Crises: Diabetic Ketoacidosis and Hyperglycemic Hyperosmolar State. Diakses tanggal 20 September 2020 dengan link https://www.ncbi.nlm.nih.gov/books/ NBK279052/

Hurtado, Helard, Gil-Olivares, FradisEriberto, Castillo-Bravo, Luis, PerezTazzo, Laura, Campomanes-Espinoza, Giovanny Carel, Aliaga-Llerena, Lagos-Cabrera, Aquilar-Cartagena. (2021). Management of Glycemic Crises in Adult Patients with Diabetes Mellitus: Evidence-Based Clinical Practice Guideline Clinical. Rev.Fac.Med.Hum, 21(1): 50-64

Huang, Kuo, Shu-Chun, Chien, Lin, HungJung, Guo, Chen, Wei-Lung, . . . Su, Shih-Bin. (2013). Predicting the Hyperglycemic Crisis Death (PHD) 
Score: a New Decision Rule for Emergency and Critical Care. American Journal of Emergency Medicine, 31, 830-834. doi: http://dx.doi.org/10.1016/j.ajem.2013. 02.010

Kjeldsen. (2010). Hypokalemia and Sudden Cardiac Death. Experimental \& Clinical Cardiology, 15(4), e96-e99. Diakses di https://www.ncbi.nlm.nih.gov/pmc/arti cles/PMC3016067/pdf/ecc15e096.pdf

Kinoshita, Tomoe, Kaneto, Hideaki, Kawasaki, Fumiko, Anno, Takatoski, Kurihara, Takeyuki, Yamada, Haruki, Oshiro, Yoshiyuki, Miyashita, Naoyuki, Okimoto, Niro, Kaku, Kohei. (2018). Fulminant Type 1 Diabetes Mellitus Complicated with a Life threatening Electrolyte Abnormality and Abnormal Electrocardiogram Findings. Intern Med, 57 (18): 26852688 .

doi: 10.2169/internalmedicine.0680-17

Liamis, Liberopoulos, Barkas, \& Elisaf. (2014). Diabetes Mellitus and Electrolyte Disorders. World Journal of Clinical Cases, 2(10), 488-496. DOI: 10.12998/wjcc.v2.i10.488

McNaughton, Wesley, Self, \& Slovis. (2011). Diabetes in the Emergency Department: Acute Care of Diabetes Patients. Clinical Diabetes, 29(2), 5159. DOI: https://doi.org/10.2337/diaclin.29.2.51 Nanette, \& Catherine. (2010). Glucose and Electrolyte Disorders General Medical Care: Emergent Medical Care (Vol. 3). Philadelpia: Mosby Elsevier.

Ness-Otunnu, \& Hack. (2013). Hyperglycemic Crisis. The Journal of Emergency Medicine, 45(5), 797-805. doi:

http://dx.doi.org/10.1016/j.jemermed.2 $\underline{013.03 .040}$
Nyenwe, \& Kitabchi. (2011). Evidencebased Management of Hyperglycemic Emergencies in Diabetes Mellitus. Diabetes Research and Clinical Practice, 94, 340-351. doi: doi:10.1016/j.diabres.2011.09.012

Pollock, \& Funk. (2013). Acute Diabetes Management Adult Patients With Hyperglycemic Crises and Hypoglycemia. AACN Advanced Critical Care, 24 (3), 314 - 324. DOI: 10.1097/NCI.0b013e31829b7d38

Quality \& Patient Safety Committee, (2014). Clinical Policies, Procedures \& Guidelines. Rhw.

Vishnu, VY; Kattadimmal, A; Rao, S; Kdhiravan, T. (2014). Sporadic Hypokalemic Paralysis Caused by osmotic Diuresis in Diabetes Mellitus. Journal of Clinical Neuroscience, 21, 1267-1268. doi: 10.1016/j.jocn.2013.10.024.

Westerberg. (2013). Diabetic Ketoacidosis: Evaluation and Treatment. American Academy of Family Physicians, 87(5), 337-346. Diakses dari https://www.aafp.org/afp/2013/0301/p $\underline{337 . p d f}$ 